\title{
Erken Çocukluk Döneminde Sosyal Beceri Ölçeği Türkçe formunun geçerlik ve güvenirliği*
}

\author{
The validity and reliability of Turkish form of the social skills scale in \\ early childhood
}

\begin{abstract}
Makale Geçmişi
Geliş : 29 Nisan 2020

Düzeltme : 5 Temmuz 2021

Kabul : 25 Ağustos 2021
\end{abstract}

\section{Makale Türü}

Araștirma Makalesi

\section{Article History \\ Received : 29 April 2020 \\ Revised : 5 July 2021 \\ Accepted : 25 August 2021}

\section{Article Type}

Research Article

\author{
Hafize Karaşahin ${ }^{1}$, Tarık Totan², Gökhan Aksu
}

\begin{abstract}
Öz: Sosyal beceri gelişimini desteklemek erken çocukluk eğitiminin önemli konu başlıklarından biridir. $\mathrm{Bu}$ sebeple de sosyal beceriyi değerlendiren ölçme araçları erken çocuklukta sıklıkla kullanılmaktadır. Ancak bilişsel gelişim erken çocukluk döneminde yeterli gelişim düzeyinde olmadığ için çoğu zaman çocukların sosyal beceri düzeylerini açık olarak ölçme araçlarıyla puanlanması olanaklı değildir. Bundan dolayı genelde çocukların bu dönemdeki sosyal becerileri onların ebeveynleri, ilk bakıcıları ya da öğretmenleri tarafindan değerlendirilmektedir. Bu araştırmada da annelerin değerlendirmesi üzerinden erken çocukluk dönemi için geliştirilmiş olan Sosyal Beceri Ölçeği'nin Türkçe geçerlik ve güvenirlik çalışması yürütülmüştür. Araştırmaya Manisa Ilinde 508 çocuğun annesi katılmışıtır. Araştırmada veri toplama araçları olarak Sosyal Beceri Ölçeği, Sosyal Becerileri Değerlendirme Ölçeği, Okul Öncesi Çocuklar için Davranış Ölçeği, Anaokulu ve Anasınıfı Davranış Ölçeği, Sosyal Beceri Geliştirme Sistemi Aile Formu ve Kişisel Bilgi Formu kullanılmıştır. Araştırma analizlerinde klasik ve modern test yöntemleri işleme alınmıştır. Elde edilen sonuçlara göre Sosyal Beceri Ölçeğinin üç faktörlü yapısını koruduğuna ulaşılmıştır. Ölçme aracı erken çocukluk eğitiminde eğitsel etkinlikleri planlamada ve dönem araştırmalarında kullanılabilecek yeterliğe sahiptir.
\end{abstract}

Anahtar Kelimeler: Sosyal Beceri, Erken Çocukluk, Ölçek, Geçerlik, Güvenirlik

Abstract: The supporting social skill development is one of the important topics of early childhood education. However, since cognitive development is not at a sufficient level of development in early childhood, it is often not possible to clearly score children's social skill levels with measurement tools. Therefore, many times it isn't possible for children to score their observed social skill levels explicitly. For this reason, the social skills of the children in this period are generally evaluated by their first parents, caregivers or teachers. In this study, the Turkish validity and reliability study of the Social Skills Scale, which was developed for early childhood, was carried out based on the evaluation of the mothers. The research was conducted from the mother of 508 children in the province of Manisa. The Social Skills Scale, the Social Skills Assessment Scale, the Behavior Scale for Preschool Children, Kindergarten and the Kindergarten Behavior Scale, the Social Skill Development System Family Form and the personal information form were used as data collection tools. In research analysis, classical and modern test theories were processed. According to the results, it was reached that the Social Skill Scale preserves its three-factor structure. The measurement tool has the competence to be used in planning and researching educational activities in early childhood education.

Keywords: Social Skill, Early Childhood, Scale, Validity, Reliability 


\section{SUMMARY}

\section{Introduction}

Throughout his life, human has to interact with other individuals. The baby, born with the need for adults rather vulnerable to other creatures, needs the support of his parents, especially his mother, to survive. In the following years, early childhood education is an ideal place to support the development of children in social skills. In these institutions, some social skills are learned from peers without being structured, while others are educated (Winkelstern \& Jongsma, 2006, Baylot Casey \& Carter, 2016). For this reason, it makes social skills education even more important in early childhood education. It is very important to make regular measurements by using different assessment techniques together in order to reveal the social skills in the most accurate way and to reveal the social skills of the children (Gülay \& Akman, 2009). In Turkey, there were scales developed and adapted to determine the social skills of preschool children and they are used frequently (Kamaraj, 2004; Seven, 2007; Acun Kapıkıran, İvrendi \& Adak, 2006; Avcığlu, 2007; Okyay, 2008; Koçyiğit \& Kay1lı, 2008; Alisinanoğlu and Özbey, 2009; Neslitürk, 2013). However, a new measurement tool is very important in terms of enriching the studies to evaluate social skills. In this study, it is aimed to adapt the Social Skills Scale prepared by Anme et al. (2013) to Turkish, which is an alternative measurement tool that will enable children to determine their social skills in early childhood education.

\section{Method}

This research is a descriptive study based on a survey method. This study, which aims to adapt the Social Skills Scale developed by Anme et al. (2013) to Turkish, was carried out with 508 students' mother. In the adaptation process, forward and backward translations were made by four experts working independently. Then, the scales were applied to 20 parents to test the comprehensibility of the scale by the families, and it was asked to mark the incomprehensible items. The data obtained in the study were analyzed using the ONYX package recommended for use in two-category responses under the $R$ program (Oertzen, Brandmaier \& Tsang, 2013). In item total correlations, Pearson Moments Product correlation coefficient and internal consistency analyzes, analyzes for KR-21 were performed with SPSS. Confirmatory factor analysis was used to determine the construct validity of the measurement tool adapted in the study and to determine the level of verification of the model formed by the researcher (Kline, 2005). In addition, in the analysis of the data, evidence of the validity of the items in the scale was presented with the Rasch analysis and the Changing Item Function based on a Parameter Model within the scope of the Item Response Theory. Whether the items in the scale according to gender variable are biased with the variable differential item functioning (Hambleton, 2006; Sireci \& Mullane, 1994). In order to determine the reliability of the adapted Social Skills Scale in terms of stability, the same scale was applied to the same group after two weeks. 


\section{Results}

In this study, it was aimed to adapt the Social Skills Scale developed by Anme et al. (2013) to Turkish and to present evidence about the reliability and validity of the scale. It was determined that the model was statistically significant $\left(\chi^{2}=3704.64 ; \mathrm{df}=210 ; p<.05\right)$. In addition, all factor loadings related to the items were found statistically significant and it was determined that both the factor load value in the relevant dimension and the overall factor load value related to how it contributed to the whole scale were greater than .40 . From the goodness statistics obtained for the whole model, $\chi^{2} / \mathrm{df}=1.25, \mathrm{NFI}=.937$, TLI $=.985$, $\mathrm{GFI}=.966, \mathrm{NNFI}=.957, \mathrm{CFI}=.987$ and RMSEA $=.002$. In the study, the WMS and UMS values of the items in the scale were found to be between 0.50 and 1.50, which are considered as the ideal range. Similarly, Standardized WMS and UMS values related to the items in the scale were found to be ideally between -1.90 and 1.90. As a result of the DMF analysis conducted to determine whether the items in the measurement tool produce different results for girls and boys, it was determined that the chi-square values obtained for all the items except the items with the code $\mathrm{m} 19$ and $\mathrm{m} 22$ were not statistically significant in the degree of freedom determined. In addition, according to the DMF analysis results obtained for male and female participants, it was determined that 20 items in the 22-item measuring instrument had the function of changing item at A level. This result explains that the measurement tool does not work in favor of women or men. The results of test-retest reliability showed that the relations between the two applications the total of the scale $.65\left(r^{2}=.42\right)$ level was found to be statistically significant in a positive relation. According to the results obtained, when the internal consistency coefficients of the Social Skill Scale were examined, it was determined that the lowest Cooperation dimension was .72, then Self-control dimension was .73, Right Search dimension was .76 and the scale was .79. Accordingly, when the results obtained regarding the reliability and validity of the measurement tool are analyzed as a whole, it is determined that a measurement tool that can measure the social skills of children in early and early education is obtained with an adapted measurement tool.

\section{Conclusion and Discussion}

The results of this research showed that the scale adapted in early childhood can also be used to evaluate the social skills of early children. In the study, the Social Skills Scale was evaluated with the data collected from the mothers of preschool children. In later researches, the Social Skills Scale can be answered by teachers. Findings from mothers and teachers can be used for multiple data confirmation. It is thought that the validity and reliability study scale can be used by researchers who want to scale social skills. In researches where social skills are studied experimentally, the scale can be used to determine children's social skill development. In longitudinal studies examining the developmental process of social skills, the scale can be used to measure social skill levels. The scale can be used in all comparative descriptive or relational models. 


\section{GİRİŞ}

Diğer canlılara oranla oldukça savunmasız, yetişkinlerine ihtiyaç duyarak dünyaya gelen bebek, yaşayabilmek için ebeveynlerine özellikle de annesinin desteğine gereksinim duyar. Bu gereklilik nedeniyle bireyin bir an önce sosyal ilişkiler kurması bir zorunluluktur (Günindi, 2008; Ziv, 2013). Geçmişte büyük ailelerde sosyal ilişkiler kurmak çok daha kolayken günümüzde ailelerin birey sayısının azalması diğer bir ifadeyle toplumun büyük bir kısmının çekirdek ailelerden oluşması, çocukların sosyal beceriler kazanmasını kısmen güçleştirmektedir (Aslan ve Arslan Cansever, 2007; Seven, 2007). Modern toplumda her iki ebeveynin de bebek sahibi olduktan kısa bir süre sonra iş yaşamına dönme zorunluluğu çocukların ailelerinden ögrenecekleri sosyal becerileri öğrenmelerini erken eğitim kurumlarının üstlenmesini gerekli kılmaktadır. Bu sebeple erken çocukluk eğitimi, sosyal beceri konusunda çocukların gelişimini destekleyen ideal yolların başında yer almaktadır. Bu kurumlarda bazı sosyal beceriler yapılandırılmaksızın akranlardan öğrenilirken bazıları eğitsel olarak yapılandırılarak kazandırılmaktadır (Baylot Casey ve Carter, 2016; Winkelstern ve Jongsma, 2006). Doğal oyunlarla çocukların bilişsel veya sosyal duygusal gelişimleri desteklenirken, akranlarıla zaman geçiren çocukların öz-sayg1, duygusal dayanıklılık, öz-düzenleme, akılda tutma ve sosyal becerilerinde artış gözlenir (Johnson ve Mei-Hsuan Wu, 2019). Bu sebeple erken çocukluk eğitiminde sosyal beceri eğitimini daha da önemli kılmaktadır.

Sosyal beceriler erken çocuklukta kazanılması gereken temel becerilerdir. Aile çocuğun ilk sosyal çevresi olduğundan erken çocukluk döneminde çocuğun bakıcılarıyla kuruduğu ikili ilişkiler sosyal beceri gelişimi için kritik öneme sahiptir (Anme ve ark. 2013). Çocuk ilk sosyal davranışları, aile bireyleri ile olan etkileşimi sonucunda kazanır. Aile bireylerinin çocukla kurdukları ilişkiler çocuğun ailedeki yerini de belirler. Bir nevi aile, çocuğun sosyal kabulü kazanması için gereken ortamı oluşturur. Diğer bir ifadeyle aile çocuğa sosyal olarak kabullenilen davranışları öğrenmesi için destek olur. Aileyle çocuk arasındaki sağlıklı etkileşim, çocuğun sağlıklı kişilik geliştirmesine yardımcı olur (Yıldız Bıçakçı, 2015). Bu bağlamda çocuğun ailesiyle kurduğu iletişimin niteliği toplumsallaşması ve akran grupları içindeki etkileşimiyle yakından ilişkilidir. Çocuğun bu etkileşimler sırasında geçirdiği her türlü olumlu yaşantı çocuğun sosyal gelişimini de olumlu yönde etkiler (Dereobalı, 2005). Ebeveynler çocuklarla kurdukları bağlanma ilişkileriyle, uyguladıkları anne baba stilleri ve davranış modelleriyle, ödülü ve cezayı kullanma tarzlarıyla, çocuklarıyla kurdukları karşılıklı iletişim yapısıyla çocukların sosyal beceri gelişimlerini etkilemekte ve onların sosyalleşmeleri açısından örnek olmaktadır (Yaşar, 2015). Ancak her ne kadar aile sosyal becerilerin kazanılması için önemli bir temel oluştursa da günümüzde çoğu sosyal becerinin okuldaki eğitim ortamlarında kazanılması söz konusudur.

Erken çocukluk eğitiminde sosyal beceriler geliştirilmesi gereken akademik olmayan beceriler olarak kabul edilmektedir (Baroody, Clements ve Sarama, 2019). Bu becerilerin gelişimi sosyal yeterlik olarak belirtilen kendini ifade etme, arkadaşları ve ailesi tarafindan onaylanma, sosyal açıdan bağllık hissetme şeklindeki davranışları ve desteklendiği bir çevre ile bağlantılıdır (Akkök, 2006). Çocukların birbirlerine karşı davranışlarını da içeren sosyal beceriler, çocuk tarafından 
öğrenildiğinde yaşamın ilk yıllarında bilişsel ve duygusal gelişimin sağlıklı şekilde gelişmesine de yardımcı olur. Erken çocuk eğitiminde sağlıklı bir şekilde sosyal ilişkilerini kurup devam ettiren çocuklar, ilerleyen yıllarda da topluma uyum sağlayan mutlu bireyler olacaktır (Gülay ve Akman, 2009). Çocukların sosyal becerileri geliştikçe akademik başarıları artmakta, saldırganlık gibi davranış problemleri ve akranları tarafindan dışlanmaları azalmaktadır (Gülay, 2009; Gültekin Akduman, Günindi ve Türkoğlu, 2015; Mendez, Fantuzzo ve Chicchetti, 2002). Çocuk bu temel becerileri kazanamadığında da okul başarısında ve sosyal ilişkilerinde uyum güçlükleri yaşamaktadır (Akkök, 2006).

Sosyal beceri ile ilgili yapılmış olan birçok tanım, sosyal becerinin başkalarının ödülleriyle artış eğilimi gösterdiğini ve öğrenilebilen davranışlar olduğunu göstermiştir (Hargie, 2006). Yapılan tanımlardan yola çıkarak sosyal becerilerin temelinde edimsel koşullanma ve sosyal öğrenme kuramının olduğu görülmektedir. Edimsel koşullanma; hedefe ulaşmak için bireyin süreç içerisinde yaptığı tekrarlar sonucu davranışı öğrenmesiyle ilgilidir (Totan, 2020). Sosyal öğrenme kuramı ise; gözlemlenen davranışın sonucunda modelin almış olduğu ödül veya cezaya bağlı olarak bireyin o davranışı taklit edip etmemesiyle ilgilidir (Yeşilyaprak, 2008). Görüldüğü gibi sosyal beceriler sosyal yaşamı etkileyecek düzeydeki becerilerdir ve doğumla birlikte öğrenilmeye başlanmaktadır. $\mathrm{Bu}$ sebeple yapılan araştırmalar ilköğretim çağına kadar olan çocukların belirli bir seviyeye kadar sosyal becerileri kazanamamaları durumunda yaşamları süresince risk altında olmaları öngörülen bir durumdur (Koçyiğit ve Kayll, 2008). Bu bağlamda sosyal becerinin okul öncesi eğitimde önemli kazanımlar arasında olduğu söylenebilir.

Sosyal beceri, çocukların gözlemleri sonucu aile ve arkadaş grupları içinde onların model olmasıyla doğal bir şekilde gelişen ve belli bir kuralı olmadan öğrenilmektedir. Ancak bazı çocuklar, akranlarını gözleyerek sosyal beceri kazanamazlar. Öyle ki bu çocuklar için sosyal becerilerin sistematik şekilde öğretilmesine ihtiyaç duyulur (Avcioğlu, 2009). Çocuğa uygulanacak olan bu eğitimde, çocuğun gelişim özellikleri göz önünde bulundurulmalı ve çocuğun bireysel performansı belirlenerek programda buna yer verilmesi gerekir (Bacanl,, 2014). Sosyal beceri eğitimi programında belirtilen bu ön koşullar dikkate alındığında bireyin yaşamına olumlu katkıları ortaya çıkmaktadır. Sosyal beceri eğitimi, çocuklar arasındaki olumlu etkileşimi desteklemek, akranları arasındaki uyumu ve kabul düzeyini arttırmak ve aralarında sosyal ilişkileri olan çocukların sosyal açıdan daha uyumlu bireyler olmaları sağlayarak akranların aralarındaki ilişkiyi geliştirmektedir (Gülay ve Akman, 2009). Bu nedenle okul öncesi dönemden itibaren sosyal beceri eğitimine aile içinde başlanması, ayrıca sosyal beceri eğitiminin okul öncesi eğitimde yer alması bireyin ileriki yaşamında da sosyal açıdan becerikli olmasını olumlu yönde etkileyecektir. 
Sosyal beceriyi değerlendirmek, bireye dönüt sağlamak, sosyal beceri eksikliğini ortaya koymak amacıyla gerçekleştirilir (Gülay ve Akman, 2009). Sosyal becerilerin kompleks olması sebebiyle bu becerileri değerlendirirken çeşitli tekniklerin kullanılmasına ihtiyaç duyulur (Çiftçi ve Sucuoğlu, 2012). Bu tekniklerden formal değerlendirmede standart ölçme araçları kullanılırken, informal değerlendirmede kişinin davranışlarının gözlem yapılarak kişiyle görüşme yapılması yer almaktadır. Genel olarak bu teknikler dört gruba ayrlabilir. Bacanlı'ya göre (2014) bunlar sırasıyla; kişinin geçmişi hakkında bilgi edinimi için klinik yöntem ve vaka inceleme terimlerini içeren (1) davramışsal görüşme, kişinin kendini rapor ettiği yöntem olan (2) kendini rapor ölçümleri, bireyi çeşitli durum ve ortamlarda gözleyebilen kişilerin birey hakkındaki rapor ve yargılarını içeren (3) davranışsal göəlem ve (4) diğer tekniklendir. Diğer teknikler, gruplandırılamayan teknikleri içerir. İlk akla gelen sosyometridir. Kişilerin sosyal çevrelerinde edindikleri konumlar göz önünde bulundurularak o kişinin sosyal becerisi hakkında bir hükme varılabilir.

Değerlendirmede akla gelen ilk soru, çocuğun sosyal yeterliliğiyle alakalı bir problem olup olmadığıdır. Şayet çocuk ilişkilerinde problem yaşıyorsa bunun nedenin ne olduğu öğrenilir. Sosyal becerisi eksik olan ya da onu dışarı vuramayan çocukların gereksinimleri belirlenir. Değerlendirme sonunda yeni bir davranış öğretilir ya da çocuğun sahip olup ortaya çıkaramadığı davranışı sergilemesi için gerekli ortam hazırlanır (Çetin, Alpa Bilbay ve Kaymak, 2003). Sosyal becerinin ölçümündeki bireysel farklılıklar Thorndike ve arkadaşlarının sosyal zekayla ilgili çalışmalarına dayanmakla birlikte zaman içinde sosyal zekanın değerlendirilme güçlüğünden dolayı Guilford ve çalışma arkadaşlarının (Riggio, 1986) davranışsal zekâ çalışmalarıyla sosyal beceri tanımlamaları ve ölçümleri ortaya çıkmaya başlamıştır. Riggio'nun (1986) temel sosyal becerileri yedi faktörde ele alınmıştır. Bunlar; sözel olmayan gönderilerdeki genel bir beceriyi ölçen duygusal anlatımcılık (Emotional Expressivity), başkalarıyla kurulan ilişkide sözel olmayan gönderileri alma ve açmayla ilgili genel becerileri ölçen duygusal hassashlk (Emotional Sensitivity), duyguları kontrol etmeyi ölçen duygusal kontrol (Emotional Control), sosyal ilişkilerde sözel olarak konuşma becerilerini ölçen sosyal anlatımcılık. (Social Expressivity), sosyal davranışları anlama ve onlara duyarlı olmayı ölçen sosyal hassashk (Social Sensitivity), sosyal ortamlarda kendini sunmayı ölçen sosyal kontrol (Social control) ve son olarak genel tutum ve uyumu ölçen sosyal manipulasyon (Social Manipulation) şeklindedir.

Sosyal beceri düzeyinin en doğru şekilde ortaya konulması ve çocukların sosyal becerilerinin ortaya çıkarılması için farklı değerlendirme tekniklerinin birlikte kullanılarak düzenli ölçümlerin yapılması oldukça önemlidir (Gülay ve Akman, 2009). Değerlendirme teknikleri içerisinde sosyal beceri ölçekleri yaygın olarak kullanılmaktadır. Ülkemizde okul öncesi dönem çocuklarının sosyal becerilerini tespit etmek amacıyla geliştirilen ve uyarlanan ölçekler bulunmaktadır ve sıklıkla kullanılmaktadır (Acun Kapıkıran, İvrendi ve Adak, 2006; Alisinanoğlu ve Özbey, 2009; Avcığlu, 
2007; Kamaraj, 2004; Koçyiğit ve Kay1l, 2008; Neslitürk, 2013; Okyay, 2008; Seven, 2007). Ancak yeni bir ölçme aracı, sosyal becerileri değerlendirmeye yönelik yapılacak çalışmaları zenginleştirme açısından oldukça önemlidir. Ülkemizde kullanılan ölçme araçları daha çok ölçek geliştirme çalışması odağında sosyal becerinin betimlenen işaret değişkenlerinin değerlendirilerek keşefedici yaklaşım kullanılarak geliştirilmiştir. Bu çalışmada uyarlanan ölçek ise kuramsal bir yaklaşımla geliştirilmiştir. $\mathrm{Bu}$ ölçeğin uluslararası karşılaştırmalarda daha tutarlı sonuçlar verebileceği düşünülmektedir. Sonuç olarak bu araştırmada da erken çocuk eğitiminde çocukların sosyal becerilerini belirlemeye olanak tanıyacak alternatif ölçme araçlarından Anme ve arkadaşları (2013) tarafından hazırlanan Sosyal Beceri Ölçeği’nin Türkçe’ye uyarlanması hedeflenmiştir.

\section{YÖNTEM}

\section{Araştırma türü}

\section{Araştırmanın katılımcıları}

Araştırma sırasında yaşları 3,5 ile 7 arasında değişen 237’si (\%46,6) kız, 268’i (\%52,7) erkek ve 3’ü $(\% 0,7)$ veri toplama formunda cinsiyet seçeneği işaretlenmemiş toplam 508 okul öncesi eğitimi alan çocuğun annesi araştırmanın katılımcı grubunu oluşturmuştur. Bu çocukların 19’u (\%3,7) 4 yaşında, 106’sı (\%20,9) 5 yaşında, 355’i (\%69,9) 6 yaşında ve 21’i (\%4,1) ise 7 yaşında olduğu belirlenmiştir. Ancak 7 (\%1.4) çocuğun yaşı boş bırakılmıştır. Çocukların 265’i (\%52,1) birinci sırada, 177’ si (\%35) ikinci sırada, 25’i $(\% 4,9)$ üçüncü sırada ve 2’si $(\% 0,4)$ dördüncü sırada doğmuştur. Çocukların annelerin yaş ortalamalarına bakıldığında 32 yaş; babaların yaş ortalamaları ise 35 yaş olduğu belirlenmiştir. Annelerin öğrenim durumu incelendiğinde 182'si (\%35,9) ilkokul, 109’u (\%21,5) ortaokul, 128’i (\%25,2) lise, 82’si (\%16,2) önlisans veya lisans, 5’i de (\%0,9) lisansüstü mezunudur. Sadece $2(\% 0,3)$ katılımcı öğrenim durumunu belirtmemiştir. Babaların öğrenim durumu incelendiğinde 122'si (\%24) ilkokul, 86’s1 (\%17) ortaokul, 175’i (\%34,5) lise, 105’i (\%20,7) önlisans veya lisans, 13’ü de $(\% 2,5)$ lisansüstü mezunudur. Araştırma verisinde $7(\% 1,3)$ babanın eğitim durumu belirtilmemiştir. Ailelerin evlilik süreleri 2 ile 29 yıl arasında değişkenlik göstermektedir. Ailelerin aylık ortalama gelirinin ise 2.372 TL olduğuna ulaşılmıştır. Ayrıca bu katılımcı grubuna ek olarak ölçeğin zaman içindeki kararlılı̆̆ını belirlemek amacıyla, örneklemden tesadüfí yolla belirlenen 61 anneye iki hafta ara ile ölçek tekrar uygulanmıştır.

\section{Araştırmada Kullanılan Veri Toplama Araçları}

Sosyal Beceri Ölçĕ̆i (Anme ve ark. 2013) 
$\mathrm{Bu}$ araştırma kapsamında Türkçeye uyarlanan bu ölçek Anme ve arkadaşları (2013) tarafından geliştirilip 2000- 2009 yıllarında Japonya'da 1 ve 6 yaş arasındaki 30.993 çocuğa uygulamışlardır. Geçerlik güvenirlik çalışması yapılan bu ölçek çocuğun sınıf içindeki davranışlarını ölçen 24 maddeden ve 3 alt faktörden oluşmaktadır. Bu alt faktörler; $\dot{I}_{s}$ birlï̆i (cooperation), Öz-kontrol (self-control) ve Hakkım arama (assertion) şeklindedir. Anme ve çalışma arkadaşları (2013) yapı geçerliği çalışmaları sırasında ölçek maddelerinin madde faktör yüklerinin .39 ile .91 arasında olduğuna ulaşmışlardır. Araştırma katılımcılarında yaşla birlikte işbirliği yapma, kendini kontrol etme ve hakkını arama davranışlarında artış eğilimi olduğunu belirlemişlerdir. Ölçeğin alt faktörlerinin sosyal yeterlik, iletişim becerileri, dil gelişimi ve zekâ gelişimiyle pozitif yönde anlamlı ilişkiler gösterdiğine ulaşmışlardır. Her bir madde "evet” ve "hayır” şeklinde cevaplanmaktadır. Doğru cevaplar için 1 puan yanlış cevaplar için 0 puan verilmektedir. Ölçekten alınan yüksek puan çocuğun sosyal becerilerinin yüksek olduğunu göstermektedir.

\section{Sosyal Becerileri Değerlendirme Ölçeği (Avc1oğlu, 2007)}

4-6 yaş grubu çocukların sosyal becerilerini değerlendirmek amacıyla geliştirilmiştir. Avcıŏ̆lu (2007) ölçeğin kapsam ve yap1 geçerliğini incelemiştir. Yap1 geçerliğinde ölçek maddelerinin 9 faktörlü yapıda toplam varyansın \%68.08’ini açıkladığını belirlemiştir. Araştırmacı ölçeğin toplamında Cronbach alfa güvenirlik katsayısını .98, iki yarı güvenirlik katsayısını .89 ve test- tekrar test güvenirlik katsayısını .83 olarak belirlemiştir. Alt ölçeklerin iç tutarlık katsayılarının .78 ile 95 arasında olduğuna ulaşmıştır. Ölçekte 62 madde ve 9 alt başlık bulunmaktadır. Bu alt faktörler; Kişiler Arası Beceriler, Kıagınlı Davranıslarm Kontrol Etme Becerileri, Akran Baskısı ile Başa Çıma Becerileri, Kendini Kontrol Etme Becerileri, Sözel Açılama Becerileri, Sonuclar Kabul Etme Becerileri, Dinleme Becerileri, Amaç Oluşturma Becerileri ve Görevleri Tamamlama Becerileridir. Beşli dereceleme şeklinde oluşturulan Likert tipi bu ölçekte, ‘5-her zaman yapar', '4-çok sik yapar', '3-genellikle yapar', '2-çok az yapar' ve '1-hiçbir zaman yapmaz' seçenekleriyle değerlendirme yapıldığı görülmüştür (Avcıoğlu, 2007). Araştırmacı ölçeğin toplamında Cronbach alfa güvenirlik katsayısını .98, iki yarı güvenirlik katsayısını .89 ve test- tekrar test güvenirlik katsayısını .83 olarak belirlemiştir. Alt ölçeklerin iç tutarlık katsayılarının .78 ile .95 arasında olduğuna ulaşmıştır. Ölçeğin toplamı için bu araştırmada ulaşılan Cronbach alfa iç tutarlılık katsayısı alt faktörlerde .75-.92 toplam puanda ise .95 olarak belirlenmiştir.

\section{Okul Öncesi Çocuklar için Davranış Ölçeği (Merrel, 2003; Okyay, 2008)}

Merrell'in (2002) geliştirdiği ve Okyay'nın (2008) Türkçe’ye uyarlayarak geçerlik güvenirlik çalışmasını yaptığı Okul Öncesi Dönem Çocuklar İçin Davranış Ölçeği (OÇDÖ), 3 ve 6 yaş arasındaki okul öncesi dönem çocuklarının sosyal becerilerinin değerlendirilmesi amacıyla geliştirilmiş bir ölçme aracıdır. 28 madde ve 2 alt faktörden oluşmaktadır. Bu alt faktörler; (1) Sosyal 
ifade ve (2) Sosyal işbirliğidir. Maddelerin faktör yüklerinin .48 ile .83 arasında olduğu raporlanmıştır. Ölçeği yanıtlayanlar derecelendirme 0 ile 4 arası (1-asla, 2-nadiren, 3-bazen ve 4-sık s1k) seçenekleri duruma en uygun olacak şekilde işaretlemektedirler. Ölçeğin yapı geçerliği için faktör analizi uygulanmış ve sonucunda Kaiser-Meyer-Olkin örneklem uygunluğu katsayısının .92 ve Barlett küresellik testi sonucunun 3709,196 (p<0.01) düzeyindedir. Araştırmada (Okyay, 2008) ölçeğin faktör yüklerinin iki farklı alt faktörde .44 ile 87 arasında, açıklanan varyansın \%34.23 düzeyinde, iç tutarlılıkların ise .89 ile .96 olduğu rapor edilmiştir. Daha sonrasında Fazlıoğlu, Okyay ve Ilgaz (2011) Sosyal Beceri Ölçeğinin üç faktörlü yapısı için yürüttükleri doğrulayıcı faktör analizi sonucunda birinci düzeyde yap1 ve araştırma verisi arasında yeterli uyum olduğunu da rapor etmişlerdir. Okul Öncesi Çocuklar için Davranış Ölçeğinin Sosyal Beceriyi ölçen kısmına ait iç tutarlık değeri alt faktörlerde .81-.86 arasında toplamda ise .91 'dir.

\section{Anaokulu ve Anasınıfi Davranı̧̧ Ölçĕgi (Merrel, 2003; Alisinanoğlu ve Özbey, 2009)}

Ölçme aracı Merrell'in (2003) daha önceki çalışmalarının devamı niteliğinde okul öncesi dönem çocuklarının sosyal beceri ve problem davranışlarını ölçmek amacıyla geliştirilmiştir. Türkçe uyarlanması ve geçerlik güvenirlik çalısmaları Alisinanoğlu ve Özbey (2009) tarafından yapılmıştır. Çalışmada Sosyal Beceri ve Problem Davranış Ölçeklerinden oluşan ölçme aracının Sosyal Beceri kısmı kullanılmıştır. Sosyal Beceri Ölçeği 23 maddeden oluşmakta, sosyal işbirliği, sosyal bağımsı̨̊hk ve sosyal kabul becerileri ile sosyal etkileşim olmak üzere üç alt faktörü barındırmaktadır. Alisinanoğlu ve Özbey (2009) ölçeğin kapsamı için uzman geçerliği çalışması yürüterek yeterli uygunluğun olmadığını belirlediği 40. maddeyi ölçme aracından çıkarmıştır. Yap1 geçerliğinde Sosyal Beceri Ölçeğinin üç alt faktörlü yapıda varyansın toplamda \%61,17'sini açıkladığını belirlemiştir. Doğrulayıcı faktör analizinde üç faktörlü yapının doğrulandığına ulaşmışıır $\left(\chi^{2} / \mathrm{sd}=2,00, \operatorname{RMSEA}=\right.$ $.006, \mathrm{NFI}=.92, \mathrm{CFI}=.96, \mathrm{GFI}=.90)$. Alt faktörlerin Cronbach Alfa değerleri .88 ile .92 arasındayken toplamı için .94 düzeyindedir. Bu araştırmada ölçeğin toplamında Cronbach alfa katsayısının alt faktörlerde .78-.85 toplamda ise .87 olduğuna ulaşılmıştır.

\section{Sosyal Beceri Geliştirme Sistemi Aile Formu (Gresham ve Elliot, 2008; Neslitürk, 2013)}

Gresham ve Elliot'un (2008) geliştirdiği ve Neslitürk (2013) tarafindan Türkçe’ye uyarlanarak geçerlik güvenirlik çalışmasının yapıldığı Sosyal Beceri Geliştirme Sistemi, 3-18 yaş grubu çocukların sosyal becerilerini belirlemek amacıyla kullanılmaktadır. Ölçme aracı, Aile, Öğretmen ve Öğrenci olmak üzere 3 ölçekten oluşmaktadır. Aile Ölçeği de iki ölçekten oluşmuş olup ilki Sosyal Beceriler Ölçeği, ikincisi ise Problem Davranış Ölçeğidir. Çalışmada kullanılmış olan Sosyal Beceriler Ölçeği kısmının iletişim, işbirliği, kendini ifade etme, sorumluluk, empati, grupla bareket etme ve kendini kontrol etme 
olmak üzere 7 alt faktörü vardır. Ölçme aracı Likert tipi bir ölçektir ve '1-hiçbir zaman yapmaz', '2nadiren yapar', '3-genellikle yapar', '4-her zaman yapar' seçenekleriyle değerlendirme yapılmaktadır. Ölçme aracının güvenirliğine bakmak için Cronbach Alfa katsayısı hesaplanmıştır ve Aile Formu Sosyal Beceriler Ölçeği için .81 ile .97 olarak rapor edilmiştir. Bunun yanı sıra maddelerin toplam korelasyonlarına bakıldığında .71 ile .85 arasında değiştiği saptanmıştır (Neslitürk ve Deniz 2014). Bu çalışmada ölçeğin Sosyal Beceriler için olan kısmında iç tutarlık değerinin alt faktörlerde .81-.86 toplamda ise .90 olduğuna ulaşılmıştır.

\section{Kişisel Bilgi Formu}

Araştırmacılar tarafından ebeveynler için bilgi formu hazırlanmıştır. Kişisel Bilgi Formu'nda yer alan sorular doğrultusunda, annelerin öğrenim durumu, yaşları, meslekleri, medeni durumları, evlilik süreleri, aylık kazançları, kuruma devam eden çocuklarının cinsiyeti ve kardeş sayıları ile ilgili sorular sorulmuştur.

\section{Araştırmada veri toplama ve analizi süreci}

Ölçeğin kullanımı için özgün formu geliştirenler (Anme ve ark. 2013) arasında ilk isim olarak yer alan Dr. Anme’den gerekli izinler alındıktan sonra ölçeğin çevirisi gerçekleştirilmiştir. İki Psikolojik Danışma ve Rehberlik alan uzmanı tarafından ölçek Türkçe’ye çevrilmiştir. Ardından başka iki uzman tarafindan Türkçe form İngilizce’ye çevrilmiştir. Elde edilen İngilizce form, ölçeğin orijinal formu araştırmacıları tarafindan karşılaştırılmış Türkçe çevirinin yeterli olduğuna ulaşılmıştır. Daha sonra ölçeğin aileler tarafından anlaşılabilirliğini sınamak üzere, ölçekler 20 ebeveyne uygulanmış, anlaşılmayan maddelerin işaretlenmesi istenmiştir. Ailelerden alınan geribildirimler sonucunda ölçek maddelerinin herhangi bir değişikliğe gerek duyulmadan rahatlıkla anlaşılabildiği gözlenmiştir.

Ölçeğin geçerlik ve güvenirlik çalışmaları kapsamında öncelikle Manisa İl Milli Eğitim Müdürlüğünden izinler alınmıştır. Araştırmanın veri toplama formları Manisa ilinin Soma ilçesinde yer alan bağımsız anaokulları, ilkokul ve ortaokulların bünyesinde bulunan anasınıfları, kız meslek lisesi bünyesindeki uygulama okulları ve özel kolejlerin anasınıfları olmak üzere bu eğitim kurumlarına devam eden okul öncesi dönem çocukların annelerine görüşme yapılarak uygulanmıştır. Araştırma analizlerinde istatistiksel güç .05 olarak dikkate alınmıştır. Çalışmada ölçeğin yapı geçerliğini belirlemek amacıyla tetrakorik korelasyon matrisine dayalı olarak Maksimum Olabilirlik Yöntemi ile parametre kestirimleri gerçekleştirilmiştir. Araştırma kapsamında $R$ programı kapsamında iki kategorili yanıtlar için kullanılması önerilen ONYX paketi ile analizler gerçekleştirilmiştir (Oertzen, Brandmaier ve Tsang, 2013). Ölçekte yer alan maddelerin geçerliğine ilişkin delil sunmak amacıyla Değişen Madde Fonksiyonundan yararlanılmıştır. Kız ve erkek 
öğrenciler için maddelere verilen yanıtlar arasındaki farklılıklar Madde Karakteristik Eğrileri ile incelenmiştir. Araştırmada uyarlanan ölçekle; Avcıoğlu (2007) tarafından geliştirilen Sosyal Becerileri Değerlendirme Ölçeği, Özbey (2012) tarafindan geliştirilen Anaokulu ve Anasınıfı Davranış Ölçeği, Okyay (2008) tarafından geliştirilen Okul Öncesi Çocuklar İçin Davranış Ölçeği ve Neslitürk (2013) tarafindan geliştirilen Sosyal Becerileri Geliştirme Sistemi Ölçeğinden elde edilen puanlar arasındaki ilişkiler incelenmiştir. Ölçeğin güvenirlik çalışması kapsamında iç tutarlılık anlamında güvenirlik madde toplam korelasyon katsayılarına dayalı ve iki kategorili yanıtlar için kullanılması önerilen KR-21 katsayısı ile incelenmiştir.

\section{BULGULAR}

Araştırmanın bu bölümünde Sosyal Beceri Ölçeğinin Türkçe formunun geçerliği ve güvenirliğini incelemek amacıyla öncelikle yapı geçerliği çalışmaları yürütülmüştür. Ölçek maddeleri evet - hayır şeklinde iki kategorili (dichotomous) puanlandığı için her ne kadar doğrulayıcı faktör analizin en çok olabilirlik kestirimi kullanılmaması önerilse de R programında Heywood case durumu olarak bilinen ve standardize edilmiş faktör yüklerinin 1'in üzerinde olması veya hata varyansının negatif çıkması sorunu yaşanmamaktadır (Hancock ve Mueller, 2010). Bu nedenle iki kategorili ağırlıklandırılmış en küçük kareler yöntemi (diagonally weighted least squares=DWLS) kullanılmıştır (Mindrilla, 2010). Doğrulayıcı faktör analizi özgün modele dayalı olarak birinci düzeyde gerçekleştirilmiştir.

\section{Ölçme Aracının Geçerliğine İlişkin Bulgular}

Doğrulayıcı faktör analizi sonucunda madde 13 ve madde 17 'nin diğer maddeler ile negatif korelasyona sahip olduğu belirlenmiştir. Aynı zamanda bu maddelerin örtük değissiklerle aralarındaki yollara ait $t$ değerlerinin istatistiksel olarak anlamlı olmadığı belirlenmiştir. Bu sebeple iki madde ölçek maddeleri arasından çıkarılarak analiz tekrar edilmiştir. Analiz sonucunda kurulan ölçme modeline ilişkin Ki-kare değerinin 3704,64 olduğu, serbestlik derecesinin 210 ve modelin istatistiksel olarak anlamlı olduğu belirlenmiştir $\left(\chi^{2}=3704,64 ; \mathrm{sd}=210 ; \mathrm{p}<.05\right)$. Kurulan ölçme modeline ilişkin elde edilen sonuçlar incelendiğinde işaret değişkenler olarak maddeler ve örtük faktörler arasındaki tüm pathlerin $t$ değerlerinin istatiksel olarak önemli olduklarına ulaşılmıştır. Üç faktörlü yapıda doğrulayıcı faktör analizi sonucunda işaret değişkenlerin standartlaştırılmış madde tahminleri incelendiğinde tüm işaret değişkenlerin pozitif yönde önemli birer parametre olduklarına ulaşılmıştır. Ölçme modeline ilişkin standardize edilmiş faktör yük değerleri, standart hata değerleri, p-değerleri std.lv değerleri bir bütün olarak Tablo 1'de gösterilmiştir.

Tablo 1. Ölçme modeline ilişkin parametre kestirimleri 


\begin{tabular}{|c|c|c|c|c|c|c|}
\hline İş birliği & Faktör yükü & Hata & z-değeri & $p$-değeri & Std.fy & Std.genel \\
\hline Madde 1 & 1.000 & & & & 0.741 & 0.741 \\
\hline Madde 2 & 0.894 & 0.140 & 6.407 & 0.000 & 0.662 & 0.662 \\
\hline Madde 3 & 0.831 & 0.140 & 5.939 & 0.000 & 0.615 & 0.615 \\
\hline Madde 4 & 1.082 & 0.143 & 7.542 & 0.000 & 0.802 & 0.802 \\
\hline Madde 5 & 0.904 & 0.148 & 6.102 & 0.000 & 0.670 & 0.670 \\
\hline Madde 6 & 0.914 & 0.155 & 5.917 & 0.000 & 0.677 & 0.677 \\
\hline Madde 7 & 1.291 & 0.159 & 8.103 & 0.000 & 0.956 & 0.956 \\
\hline Madde 8 & 0.792 & 0.172 & 4.615 & 0.000 & 0.587 & 0.587 \\
\hline \multicolumn{7}{|c|}{ Öz-kontrol } \\
\hline Madde 10 & 1.000 & & & & 0.492 & 0.492 \\
\hline Madde 11 & 1.766 & 0.461 & 3.832 & 0.000 & 0.869 & 0.869 \\
\hline Madde 12 & 1.180 & 0.322 & 3.667 & 0.000 & 0.581 & 0.581 \\
\hline Madde 14 & 1.755 & 0.487 & 3.601 & 0.000 & 0.864 & 0.864 \\
\hline Madde 15 & 0.659 & 0.267 & 2.464 & 0.014 & 0.324 & 0.324 \\
\hline Madde 16 & 1.595 & 0.401 & 3.974 & 0.000 & 0.785 & 0.785 \\
\hline \multicolumn{7}{|c|}{ Hakkını arama } \\
\hline Madde 17 & 1.000 & & & & 0.816 & 0.816 \\
\hline Madde 18 & 1.152 & 0.149 & 7.723 & 0.000 & 0.940 & 0.940 \\
\hline Madde 19 & 0.884 & 0.162 & 5.458 & 0.000 & 0.721 & 0.721 \\
\hline Madde 20 & 0.612 & 0.128 & 4.793 & 0.000 & 0.499 & 0.499 \\
\hline Madde 21 & 1.118 & 0.139 & 8.050 & 0.000 & 0.913 & 0.913 \\
\hline Madde 22 & 0.880 & 0.156 & 5.628 & 0.000 & 0.719 & 0.719 \\
\hline Madde 23 & 0.984 & 0.132 & 7.458 & 0.000 & 0.803 & 0.803 \\
\hline
\end{tabular}

Tablo 1'de elde edilen sonuçlara göre birinci faktör olan İşbirliğinde standartlaştırılmamış faktör yükleri .79 ile 1.29, ikinci faktör olan Öz-kontrolde .65 ile 1.76 ve üçüncü faktör olan Hakkını aramada .61 ile 1.15 arasında yüklenmiştir. Elde edilen sonuçlarda birinci faktör için madde1, ikinci faktör için madde 10 ve üçüncü faktör için madde 18’in referans değişkeni olması sebebiyle faktör yükleri 1.00 olarak kabul edilerek diğer parametreleri hesaplanmamıştır. Bunun yanında maddelere ilişkin faktör yüklerinin tamamı istatistiksel olarak anlamlı bulunmuş ve hem ilgili faktörde faktör yük değerinin (std.fy) hem de ölçeğin tamamına nasıl bir katkı sağladığına ilişkin genel faktör yük değerinin kritik olarak kabul edilen .40'dan büyük olduğu görülmektedir (Matsunaga, 2010). Araştırmacılar tarafindan uyarlaması gerçekleşen ölçme aracının model veri uyumuna ilişkin uyum iyiliği indeksleri Tablo 2'de gösterilmiştir.

Tablo 2. DFA ile kurulan üç faktörlü ölçme modeline ilişkin model uyum indeksleri 


\begin{tabular}{|c|c|c|c|c|c|c|c|c|c|}
\hline Model & $\chi^{2}$ & SD & $\chi^{2} / \mathrm{sd}$ & NFI & TLI & GFI & NNFI & CFI & RMSEA \\
\hline $\begin{array}{l}\text { Üç } \\
\text { Faktörlü } \\
\text { Yap1 }\end{array}$ & 231,67 & 186 & 1,25 & .937 & .985 & .966 & .957 & .987 & $\begin{array}{c}.0029[0.014- \\
0.039]\end{array}$ \\
\hline Ölçütler & & & $\leq 5$ & $\geq .90$ & $\geq .85$ & $\geq .85$ & $\geq .90$ & $\geq .95$ & $\leq .08$ \\
\hline
\end{tabular}

NFI: Normed Fit Index, NNFI: Non-normed Fit Index, GFI: Goodness of Fit Index, CFI: Comperative Fit Index, RMSEA: Root Mean Square Error of Approximation

Tablo 2'de görüldüğü üzere elde edilen DFA sonuçlanına göre tüm uyum indekslerinin kabul edilebilir düzeyde olduğu, ölçekte yer alan maddelerin üç faktörlü yapıyla kurulan modelin uygun olduğu sonucuna ulaşılmıştır (Kline, 2005; Bentler, 1990; Aksu, Eser ve Güzeller, 2017). Çalışma kapsamında kullanılan ölçme aracının güvenirlik ve geçerlik analizleri jMetrik 4.1.1 programı ile gerçekleştirilmiştir. Programdan elde edilen sonuçların değerlendirilmesinde Linacre (2002) tarafından yapılan ağırlandırılmamış ve standardize edilmiş uyum istatistikleri için kullanılacak olan ölçütler için kabul edilebilir aralıklar Tablo 3'de gösterilmiştir.

Tablo 3. Uyum istatistiklerinin kabul edilebilir aralıkları

\begin{tabular}{lcl}
\hline Ölçüt & Aralık & Yorum \\
\hline & $>0,20$ & Ölçmeye konu özelliği saptırmaktadır ve ölçmenin kalitesini düşürür. \\
WMS ve & $1,50-2,00$ & Ölçme işlemi için verimsiz ama çok da kötümser değil. \\
UMS & $0,50-1,50$ & Ölçme için gayet uygun. \\
& $<0,50$ & $\begin{array}{l}\text { Ölçme işlemi için daha az verimli ancak çok kötü değil. Yüksek düzeyde güvenirlik } \\
\text { ve ayırt edicilik değeri üretebilir. }\end{array}$ \\
\hline & $\geq 3,00$ & Veriler model ile uyum göstermiyor. Daha büyük örneklem ile çalışllabilir. \\
Std.WMS ve & $2,00-2,99$ & Veriler belirgin ölçüde tahmin edilemez. \\
Std.UMS & $-1,99-1,99$ & Veriler makul düzeyde tahmin edilebilirliğe sahiptir. \\
& $\leq-2,00$ & Veriler oldukça tahmin edilebilir. Belki diğer boyutlar yanıt örüntülerini \\
& sinırlandırabilir.
\end{tabular}

Tablo 3 incelendiğinde WMS ve UMS değerleri için en ideal aralığın 0,50 ile 1,50 arasında olduğu belirlenmiştir. Benzer şekilde Standardize edilmiş WMS ve UMS değerleri için en ideal aralığın 1,90 ile 1,90 arasında olduğu söylenebilir. WMS ve Std.WMS isimli sütunlar sırasılyla ağırlıklandırılmış ve standardize edilmiş kareli ortalama uyumsuzluk istatistiklerini göstermektedir. Bunları takiben $U M S$ ve Std.UMS isimli sütunlar ağırlıklandırılmamış ve standardize edilmiş kareli ortalama ölçüt dışı olma istatistiklerini göstermektedir (Güzeller, Eser ve Aksu, 2018).

\section{Rasch Analizine İlişkin Bulgular}

Ölçekte yer alacak maddelerin belirlenmesinde sadece madde güçlük ve ayırt edicilik indekslerine bakmanın yeterli olmayacağı düşüncesiyle 1 parametreli lojistik modellerden Rasch analizi ile maddelere ilişkin dönüştürülmüş ayırt edicilik indeksleri ile uyum indeksleri hesaplanmıştır. Rasch 
analizinde Maksimum iterasyon sayısı 150, yakınsama ölçütü 0,005 ve uç değerleri düzenleme (smooting) ölçütü 0,3 olarak belirlenen parametrelere göre elde edilen madde istatistikleri Tablo 4'de gösterilmiştir.

Tablo 4. Ölçekteki maddelere ilişkin Rasch analizi sonuçları

\begin{tabular}{lcccccc}
\hline Madde No & Güçlük & Std. Hata & WMS & Std. WMS & UMS & Std. UMS \\
\hline Madde 1 & 0,03 & 0,21 & 0,93 & $-0,47$ & 0,78 & $-0,85$ \\
Madde 2 & $-0,39$ & 0,19 & 0,96 & $-0,30$ & 0,85 & $-0,72$ \\
Madde 3 & $-0,59$ & 0,18 & 1,06 & 0,54 & 1,18 & 1,00 \\
Madde 4 & 1,06 & 0,29 & 0,89 & $-0,47$ & 0,33 & $-1,97$ \\
Madde 5 & $-0,29$ & 0,19 & 0,97 & $-0,21$ & 0,95 & $-0,19$ \\
Madde 6 & 0,21 & 0,22 & 0,94 & $-0,40$ & 1,05 & 0,28 \\
Madde 7 & 1,23 & 0,30 & 0,82 & $-0,77$ & 0,23 & $-2,26$ \\
Madde 8 & 1,33 & 0,31 & 0,99 & 0,05 & 1,44 & 0,94 \\
Madde 10 & $-2,87$ & 0,14 & 1,11 & 2,20 & 1,37 & 3,41 \\
Madde 11 & 0,26 & 0,22 & 1,12 & 0,83 & 1,11 & 0,48 \\
Madde 12 & $-1,20$ & 0,16 & 0,92 & $-0,94$ & 0,79 & $-1,74$ \\
Madde 14 & $-2,28$ & 0,14 & 1,06 & 1,10 & 1,08 & 0,92 \\
Madde 15 & 0,77 & 0,26 & 0,90 & $-0,52$ & 0,63 & $-1,01$ \\
Madde 16 & $-1,15$ & 0,16 & 1,28 & 2,91 & 1,47 & 3,21 \\
Madde 17 & $-0,01$ & 0,20 & 1,05 & 0,40 & 0,77 & $-0,95$ \\
Madde 18 & 3,29 & 0,72 & 0,99 & 0,20 & 0,19 & $-0,49$ \\
Madde 19 & $-0,39$ & 0,19 & 0,88 & $-1,02$ & 0,69 & $-1,70$ \\
Madde 20 & 1,95 & 0,40 & 0,98 & 0,06 & 0,70 & $-0,26$ \\
Madde 21 & $-1,12$ & 0,16 & 1,21 & 2,25 & 1,40 & 2,76 \\
Madde 22 & $-0,29$ & 0,19 & 0,92 & $-0,66$ & 0,66 & $-1,78$ \\
Madde 23 & 0,98 & 0,28 & 0,93 & $-0,26$ & 0,79 & $-0,39$ \\
Madde 24 & $-0,53$ & 0,18 & 0,85 & $-1,34$ & 0,79 & $-1,14$ \\
\hline
\end{tabular}

Tablo 4'te gösterilen Unweighted Mean Square (UMS) ve Weighted Mean Square (WMS) fit statistics maddelere ilişkin uyum istatistikleridir. Bu değerlerden WMS infit ölçütü, UMS ise outfit ölçütü olarak kabul edilmektedir. Tablo 1 incelendiğinde 24 maddeden oluşan ölçeğin WMS ve UMS değerlerine göre yapılacak ölçme işlemi için gayet uygun oldukları görülmektedir. Her ne kadar m9, m15 ve m21 kodlu maddelerin Standardize edilmiş WMS değerlerine göre maddelerinin model veri uyumu için kabul edilebilir düzeyde olsa da ölçekte yer alan diğer maddelerin -2,00 ile 2,00 aralığında değer almış olmaları sebebiyle maddelerin uyum indekslerin ideal düzeyde olduğu belirlenmiştir (Linacre, 2002). Ölçme aracında yer alan 9. maddenin hem Std. UMS değerinin $(3,41)$ hem de Std. WMS değerinin (2,20) alan yazında Linacre (2002) tarafından önerilen -1,99 ile $+1,99$ aralığının dışında olması sebebiyle analizlerden çıkarılmasına karar verilmiştir. Bu nedenle ilgili 
madde model ile uyum göstermediğinden analiz kapsamına alınmamıştır. Benzer şekilde ölçekte yer alan 22 maddenin tamamı için elde edilen UMS ve WMS değerlerinin 0,50 ile 1,50 aralığında olması maddelerin iç ve dış uyuma sahip olduklarının göstergesidir.

\section{Değişen Madde Fonksiyonu (DMF) Analizine İlişkin Bulgular}

Çalışmada ayrıca geliştirilen ölçme aracında yer alan maddelerin yanlllık gösterip göstermediğini belirlemek amacıyla Madde Tepki Kuramına dayalı yöntemlerden Mantel-Hanzel tekniği ile cinsiyet değisskenine göre maddelere verilen yanıtların lojistik fonksiyonlar yardımıyla nasıl bir dağılım gösterdiği incelenmiştir. Analiz sonucunda elde edilen ki-kare değerleri, anlamlllık değerleri ve DMF'nin düzeyini belirten istatistikler Tablo 5'de gösterilmiştir.

Tablo 5. Cinsiyete göre değişen madde fonksiyonu sonuçları

\begin{tabular}{|c|c|c|c|c|c|c|c|}
\hline Madde & $\chi^{2}$ & $p$ & $n$ & Hata & Alt sinır & Üst sinır & Düzey \\
\hline Madde 1 & 0,03 & .86 & 189 & 0,00 & $-0,06$ & 0,06 & $\mathrm{AA}$ \\
\hline Madde 2 & 0,06 & .81 & 239 & $-0,01$ & $-0,08$ & 0,06 & $\mathrm{AA}$ \\
\hline Madde 3 & 0,30 & .58 & 249 & $-0,02$ & $-0,10$ & 0,06 & $\mathrm{AA}$ \\
\hline Madde 4 & 0,97 & .33 & 62 & 0,02 & $-0,03$ & 0,06 & $\mathrm{AA}$ \\
\hline Madde 5 & 0,07 & .78 & 246 & 0,01 & $-0,06$ & 0,08 & AA \\
\hline Madde 6 & 0,06 & .81 & 191 & $-0,01$ & $-0,07$ & 0,05 & $\mathrm{AA}$ \\
\hline Madde 7 & 0,22 & .64 & 34 & 0,01 & $-0,02$ & 0,05 & AA \\
\hline Madde 8 & 0,00 & .98 & 185 & 0,00 & $-0,04$ & 0,05 & $\mathrm{AA}$ \\
\hline Madde 10 & 0,63 & .43 & 199 & $-0,03$ & $-0,09$ & 0,04 & $\mathrm{AA}$ \\
\hline Madde 11 & 2,63 & .11 & 193 & $-0,07$ & $-0,16$ & 0,01 & BB- \\
\hline Madde 12 & 0,94 & .33 & 240 & $-0,05$ & $-0,15$ & 0,05 & $\mathrm{AA}$ \\
\hline Madde 14 & 0,86 & .35 & 135 & $-0,02$ & $-0,07$ & 0,03 & $\mathrm{AA}$ \\
\hline Madde 15 & 0,37 & .54 & 247 & $-0,04$ & $-0,13$ & 0,05 & $\mathrm{AA}$ \\
\hline Madde 16 & 0,31 & .57 & 195 & $-0,02$ & $-0,08$ & 0,04 & $\mathrm{AA}$ \\
\hline Madde 17 & 1,40 & .24 & 249 & 0,07 & $-0,04$ & 0,18 & $\mathrm{BB}+$ \\
\hline Madde 18 & 0,22 & .64 & 9 & 0,01 & $-0,01$ & 0,02 & $\mathrm{AA}$ \\
\hline Madde 19 & 4,12 & .04 & 199 & 0,07 & 0,01 & 0,14 & $\mathrm{BB}+$ \\
\hline Madde 20 & 0,53 & .47 & 74 & 0,01 & $-0,02$ & 0,04 & $\mathrm{AA}$ \\
\hline Madde 21 & 1,22 & .27 & 243 & 0,06 & $-0,03$ & 0,14 & $\mathrm{BB}+$ \\
\hline Madde 22 & 4,66 & .03 & 199 & 0,08 & 0,01 & 0,15 & $\mathrm{BB}+$ \\
\hline Madde 23 & 0,00 & .96 & 235 & 0,01 & $-0,03$ & 0,05 & $\mathrm{AA}$ \\
\hline Madde 24 & 3,63 & .06 & 245 & $-0,07$ & $-0,14$ & $-0,01$ & BB- \\
\hline
\end{tabular}

Tablo 5 incelendiğinde ölçme aracında yer alan maddelerden $\mathrm{m} 19$ ve m22 kodlu maddelerin haricindeki diğer tüm maddeler için elde edilen ki-kare değerlerinin belirlenen serbestlik derecesinde istatistiksel olarak anlamlı olmadığı görülmektedir. Bunun yanında kız ve erkek katılımcılar için elde edilen DMF analizi sonucuna göre 22 maddelik ölçme aracında yer alan 20 maddenin A (önemsiz) 
düzeyde DMF sahip olduğu belirlenmiştir (Güzeller, Eser ve Aksu, 2018). Elde edilen bu sonuç ölçme aracının kadın veya erkeklerin lehine çalışmadığını ve her iki grup için de ölçme aracından elde edilen sonuçların önemsiz düzeyde farklılık gösterdiğini açıklamaktadır. Ancak ölçme aracında yer alan maddelerden m19 ve m22 kodlu maddelerin BB+ (orta) düzeyde odak grup lehine DMF gösterdiği belirlenmiştir. Bir maddenin çalışma evreninde yer alan alt gruplardan birinin lehine veya aleyhine yanlı sonuçlar ürettiğini söyleyebilmek için en az C (yüksek) düzeyde DMF göstermesi gerekmektedir (Koyuncu, Aksu ve Kelecioğlu, 2018). Orta düzeyde DMF gösterdiği belirlenen 2 madde için madde karakteristik eğrileri Şekil 1'de gösterilmiştir.
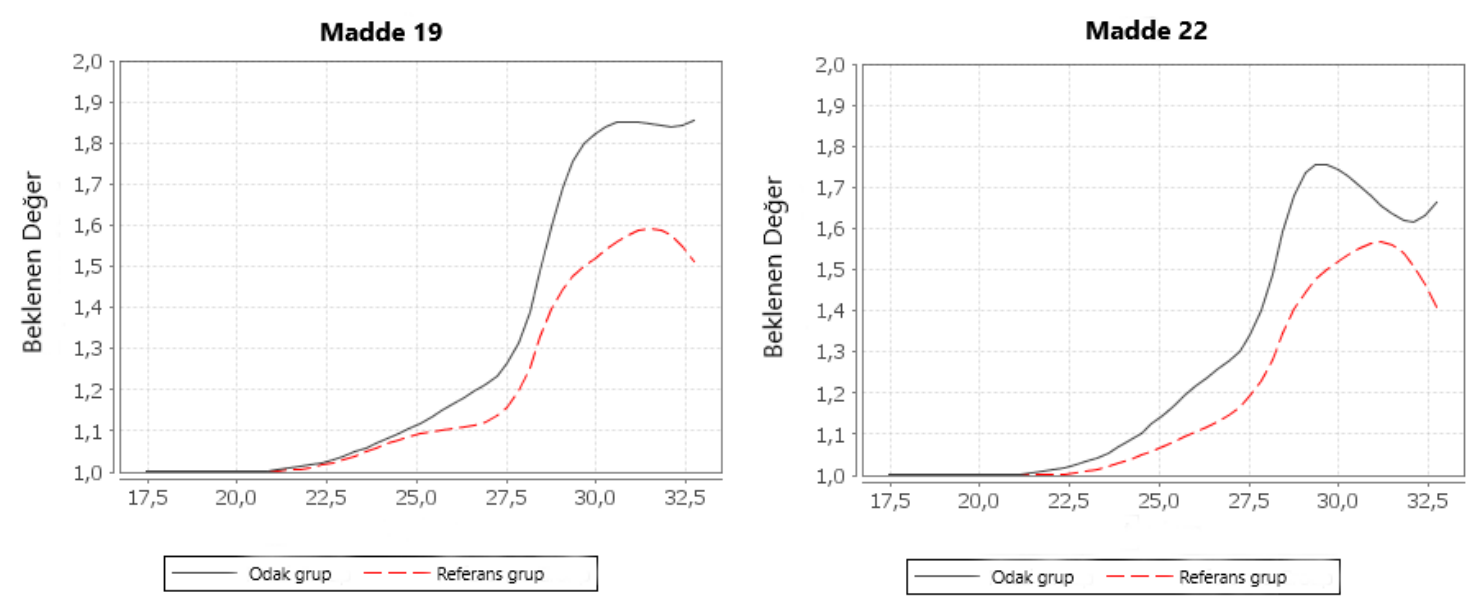

Şekil 1. Maddelere ilişkin madde karakteristik eğrileri

Şekil 1 incelendiğinde her iki madde için odak ve referans grupları olarak belirlenen kız ve erkek öğrenciler için verilen yanıt örüntüleri incelenerek elde edilen doğru yanıtlanma olasılıkları arasındaki farkın oldukça düşük olduğu görülmektedir. Nitekim lojistik fonksiyon yardımıyla elde edilen eğriler arasındaki farkın da orta düzeyde olması ölçme kız ve erkek öğrenciler için benzer sonuçlar ürettiğini ve her iki grup için de ölçme aracından elde edilen sonuçların önemsiz düzeyde farklılık gösterdiğini açıklamaktadır. Toplam üç alt faktör ve 22 maddeden oluşan ölçme aracından elde edilen sonuçlar için MTK ile belirlenen test bilgi fonksiyonu Şekil 2’te gösterilmiştir. 


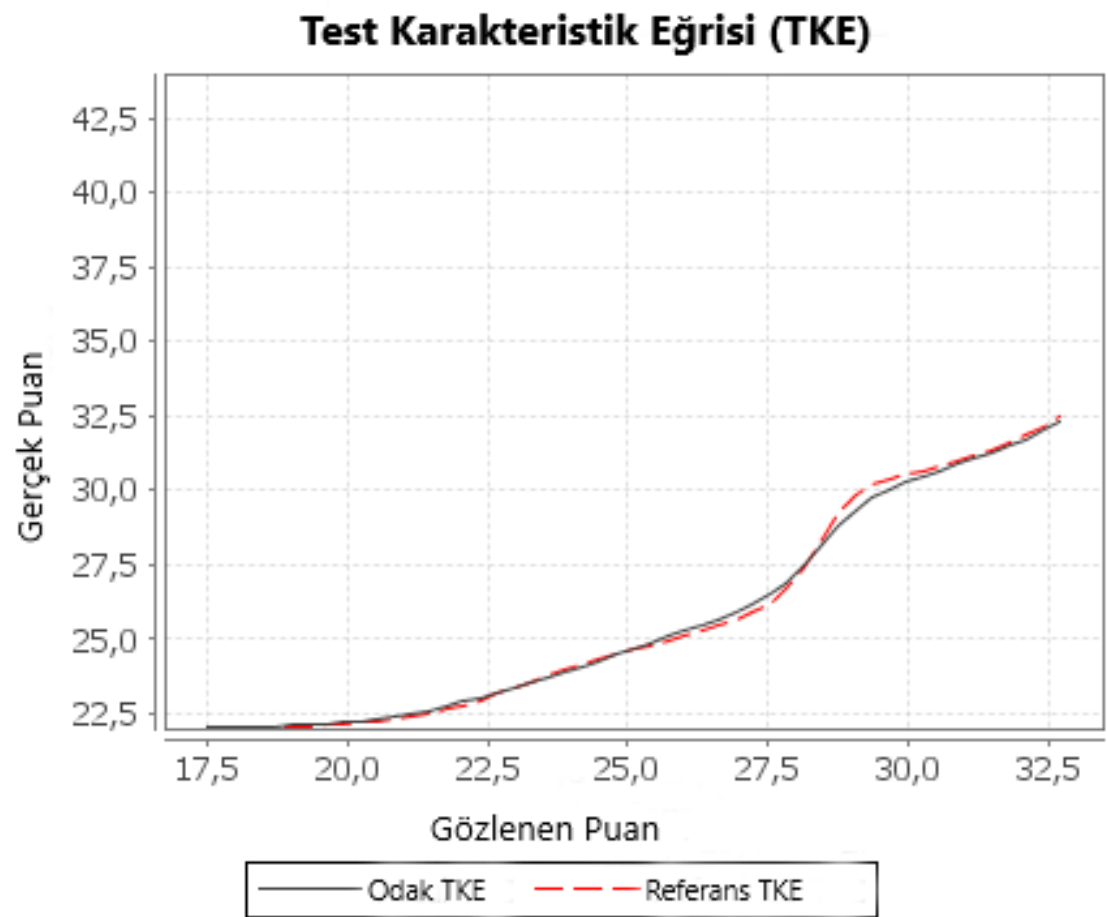

Şekil 2. Testin tamamına ilişkin test bilgi fonksiyonu

Testin tamamı için odak ve referans grubu olarak belirlenen kız ve erkek öğrenciler için testtin tamamından elde edilen puanların nasıl bir dağılım gösterdiğinin belirlenmesi amacıyla Şekil 2'de elde edilen sonuçlar incelendiğinde her iki grup arasında anlamlı bir farklılık olmadığı görülmektedir. Buna göre ölçme aracının güvenirlik ve geçerliğine ilişkin elde edilen sonuçlar bir bütün olarak incelendiğinde, uyarlanan ölçme aracı ile erken çocuk eğitiminde çocukların sosyal becerilerini güvenilir ve geçerli bir şekilde ölçülebilecek bir ölçme aracının elde edildiği belirlenmiştir.

\section{Sosyal Beceri Ölçeğinin Benzer Ölçek Geçerliği}

Sosyal Beceri Ölçeği’nin benzer ölçek geçerliği daha önce geliştirilen, geçerliği ve güvenirliği Türkçe'de kanıtlanan Sosyal Becerileri Değerlendirme Ölçeği, Okul Öncesi Çocuklar İçin Davranış Ölçeği, Anaokulu ve Anasınıfı Davranış Ölçeği ve Sosyal Beceri Geliştirme Sistemi ölçekleriyle ilişkileri incelenerek araştırılmıştır. Pearson Momentler Çarpımı Korelasyon katsayısı kullanılarak elde edilen sonuçlar Tablo 6'da gösterilmiştir. 
Tablo 6. Sosyal Beceri Ölçeğin Benzer Ölçek Geçerliği

\begin{tabular}{|c|c|c|c|c|c|}
\hline Benzer ölçekler & & $\begin{array}{c}\dot{\text { İş }} \\
\text { birliği }\end{array}$ & $\begin{array}{c}\text { Öz- } \\
\text { Kontrol }\end{array}$ & $\begin{array}{l}\text { Hakkinı } \\
\text { arama }\end{array}$ & $\begin{array}{c}\text { Sosyal } \\
\text { Beceri } \\
\text { Toplam }\end{array}$ \\
\hline Sosyal Becerileri & Kişiler arası beceriler & .44 & .32 & .42 & .54 \\
\hline \multirow{9}{*}{$\begin{array}{l}\text { Değerlendirme Ölçeği } \\
\text { (Avcıoğlu, 2007) }\end{array}$} & Kızgınlık Davranışlarını Kontrol Etme ve & .31 & .26 & .31 & .40 \\
\hline & Değişikliklere Uyum Sağlama Becerileri & & & & \\
\hline & Akran Baskısı ile Başa Çıkma Becerileri & .33 & .31 & .28 & .42 \\
\hline & Sözel Açıklama Becerileri & .33 & .18 & .38 & .40 \\
\hline & Kendini Kontrol Etme Becerileri & .18 & .31 & .12 & .30 \\
\hline & Amaç Oluşturma Becerileri & .20 & .16 & .27 & .28 \\
\hline & Dinleme Becerileri & .27 & .28 & .30 & .39 \\
\hline & Görevleri Tamamlama Becerileri & .26 & .23 & .21 & .32 \\
\hline & Sonuçları Kabul Etme Becerileri & .20 & .32 & .17 & .32 \\
\hline \multirow{5}{*}{$\begin{array}{l}\text { Anaokulu ve Anasınıfi } \\
\text { Davranış } \\
\text { Ölçeği(Özbey,2012) }\end{array}$} & Sosyal İşbirliği Becerileri & .26 & .44 & .20 & .44 \\
\hline & Sosyal Bağımsızlık ve Sosyal Kabul & .28 & .19 & .39 & .38 \\
\hline & Becerileri & & & & \\
\hline & Sosyal Etkileşim Becerileri & .37 & .19 & .28 & .37 \\
\hline & Toplam & .37 & .37 & .36 & .50 \\
\hline \multirow{9}{*}{$\begin{array}{l}\text { Okul Öncesi Çocuklar } \\
\text { İçin Davranış Ölçeği } \\
\text { (Okyay, 2008) } \\
\text { Sosyal Becerileri } \\
\text { Geliştirme Sistemi } \\
\text { (Neslitürk, 2013) }\end{array}$} & Sosyal İfade & .36 & .16 & .33 & .38 \\
\hline & Sosyal İşbirliği & .28 & .44 & .27 & .47 \\
\hline & İşbirliği & .31 & .40 & .27 & .46 \\
\hline & Kendini İfade Etme & .32 & .14 & .35 & .36 \\
\hline & Empati & .40 & .27 & .36 & .46 \\
\hline & Kendini Kontrol Etme & .36 & .42 & .29 & .50 \\
\hline & İletişim & .33 & .28 & .43 & .47 \\
\hline & Grupla Birlikte Hareket Etme & .33 & .13 & .41 & .39 \\
\hline & Sorumluluk & .32 & .36 & .30 & .44 \\
\hline
\end{tabular}

$* p \leq .001$

Sosyal Beceri Ölçeği’nin benzer ölçek geçerliğinde diğer ölçeklerle ilişkisi incelendiğinde sosyal beceriler toplam değerlerine göre ilişkilendirilmiştir. Sosyal Beceri Ölçeği'nin, Sosyal Becerileri Değerlendirme Ölçeği’nin alt faktörlerinden kişiler arası beceriler ile .53, kızgınlık davranışlarını kontrol etme ve değişikliklere uyum sağlama becerileriyle .40, akran baskısı ile başa çıkma becerileriyle .42 , sözel açıklama becerileriyle .40 , kendini kontrol etme becerileriyle .30 , amaç oluşturma becerileriyle .28, dinleme becerileriyle .39, görevleri tamamlama becerileriyle .32 , sonuçları kabul etme becerileriyle .32 düzeyinde anlamlı ilişki olduğu bulunmuştur. Sosyal Beceri Ölçeği’nin Anaokulu ve Anasınıfı Davranış Ölçeği’nin alt faktörlerinden sosyal işbirliği becerileriyle .44 , sosyal bağımsızlık ve sosyal kabul becerileriyle .38 , sosyal etkileşim becerileriyle .37 ve toplamda .50 düzeyinde anlamlı ilişkiler saptanmıştır. Sosyal Beceri Ölçeği’nin Okul Öncesi Çocuklar İçin Davranış Ölçeği'nin alt faktörlerinden sosyal ifadeyle .38, sosyal işbirliğiyle .47 düzeyinde anlamlı ilişki olduğu bulunmuştur. Ayrıca Sosyal Beceri Geliştirme Sisteminin Aile Formu'nun alt faktörlerinden işbirliğiyle .46, kendini ifade etmeyle.36, empatiyle .46, kendini kontrol etmeyle .50, iletişimle .47 , grupla birlikte hareket etmeyle .39 ve sorumlulukla .44 düzeyinde anlamlı ilişkiler saptanmıştır. 


\section{Ölçme Aracının Güvenirliğine İlişkin Bulgular}

Ölçme aracından elde edilen sonuçların güvenirliğine ilişkin delil sunmak amacıyla iç tutarlılık ve kararlılık anlamında güvenirlik belirleme yöntemlerinden yararlanılmıştır. Öğrencilerin yaşları göz önüne alındığında ölçekte yer alan ifadelere evet-hayır şeklinde iki kategorili yanıtlamanın duyarlılık anlamında güvenirlik varsayımını karşıladığı kabul edilmiştir.

\section{Kararlılık anlamında güvenirlik}

Sosyal Beceri Ölçeği test tekrar test güvenirliğini incelemek amactyla ölçek iki hafta arayla 61 öğrenciye uygulanmıştır. İki uygulama arasındaki ilişkiler Pearson Momentler Çarpımı Korelasyon katsayıları kullanılarak incelenmiştir. Sosyal Beceri Ölçeğinin test-tekrar test bulgularında iki uygulama arasında geçen zamandan sonra işbirliği faktöründe $.51\left(r^{2}=.26\right)$, öz-kontrolda $.47\left(r^{2}=\right.$ .22), hakkını aramada $.48\left(r^{2}=.23\right)$ ve ölçeğin toplamında ise $.65\left(r^{2}=.42\right)$ düzeyinde pozitif yönde istatiktiksel olarak anlamlı korelasyonlar belirlenmiştir. Korelasyonlara ait etki büyüklükler ise 22 ile .42 düzeyinde orta düzeydedir.

\section{İç tutarlılık anlamında güvenirlik}

Sosyal Beceri Ölçeğinin iç tutarlılık katsayılarının belirlenmesinde ölçek maddelerini 0 ve 1 şeklinde ikili kodlanmasından dolayı Cronbach alfa yerine KR-21 formülü kullanılarak yapılmıştır (Kuder \& Richardson, 1937). Elde edilen sonuçlara göre Sosyal Beceri Ölçeğinin iç tutarlılık katsayıları incelendiğinde en düşük işbirliği faktöründe .72, sonrasinda öz-kontrol faktöründe .73, hakkem arama faktöründe .76 ve ölçeğin toplamında ise .79 düzeyinde olduğu belirlenmiştir.

\section{SONUÇ ve TARTIŞMA}

Erken çocukluk döneminde sosyal beceriyi değerlendiren bir dizi ölçek bulunmaktadır. Bunlar arasında Avcioğlu'nun (2007) geliştirdiği Sosyal Becerileri Değerlendirme Ölçeği, Okyay (2008) tarafından Türkçe'ye uyarlanan ve geçerlik güvenirlik çalışması yapılan Okul Öncesi Çocuklar İçin Davranış Ölçeği (Merrel, 2003), Alisinanoğlu ve Özbey’in (2009) uyarladığı Anaokulu ve Anasınıfı Davranış Ölçeği (Merrel, 2003), Neslitürk’ün (2013) uyarladığ1 Sosyal Becerileri Geliştirme Sistemiyle (Gresham ve Elliot, 2008), Ömeroğlu ve çalışma arkadaşlarının (2014) geliştirmiş oldukları Okul Öncesi Sosyal Beceri Değerlendirme Ölçeği ve Aksoy ve Baran’ın (2020) geliştirmiş oldukları Sosyal Becerileri Değerlendirme Ölçeği - Ebeveyn Formu bulunmaktadır. Ancak yine de hali hazırda Türkçe'de erken çocukluk dönemindeki gerek kişilik örüntülerini gerekse de akademik öğrenme dışındaki eğitsel becerileri, sosyal ve duygusal öğrenme becerilerini değerlendirecek sosyal beceri bağlamında ölçme araçlarına ihtiyaç vardır. Ayrıca, Anme ve çalışma arkadaşlarının (2013) geliştirmiş olduğu Sosyal Beceri Ölçeğini diğer ölçme araçlarından ayıran yanı günlük durumları kısa 
zamanlı ölçmesidir. Ayrıca ölçme aracının evet ve hayır olarak puanlanması uygulama kolaylı̆̆ı sağlamaktadır. Bu amaçla da bu araştırmada Anme ve arkadaşları (2013) tarafından hazırlanan Sosyal Beceri Ölçeği Türkçe'de geçerlik ve güvenirliğini incelenmesi amaçlanmıştır.

Sosyal beceri Gresham ve Elliot'un (2008) Sosyal Beceri Gelişme Sistemine göre (Social Skill Improvement System) temelde yedi alt kategoriye ayrilmaktadır. Bunlar sırasıyla; temel konuşma ve kişiler arası ilişkiler kurmayla ilgili olan (1) iletişim becerileri; grup içinde ortak çalışmalarda yer alma ve paylaşımda bulunmayı değerlendiren (2) işbirliği yapma becerileri; iletişim sürecini başlatma ilgili becerileri bilmeyle şekillenen (3) kendini ifade etme becerileri; verilen görevi yerine getirme ve bu işe verdiği önemi göstermeyle ilgili olan (4) sorumluluk alma becerileri; kişilerin duygu ve düşüncelerine saygılı olma ve önem vermeyle gelişen (5) empati kurabilme becerileri; bulunduğu ortamdaki kişilerle olumlu ilişkiler kurma ve bu kişilerle arkadaşlık kurarak gerektiğinde aktivitelere katılmayla ilgili olan (6) grupla birlikte hareket etme becerileri; ve güçlü- zayıf yanlarını bilerek gerektiğinde duruma uygun tepkiler vermeyle şekillenen (7) kendini kontrol etme becerileridir. Yapılan sinıflandırmalara bakıldığında, temelde kişinin kendini ve hislerini ifade etme becerisinin olduğu görülmektedir. Konuşmayı başlatma ve sürdürme, arkadaşlarıyla ilişkilerini yönetme, başkalarının duygularını anlama, paylaşma, yardım etme ve yardım isteme gibi becerileri sınıflandırmalar arasındadır. Bireyin bu becerilere sahip olması sosyal bakımdan yeterli düzeyde olduğunu gösterirken, eksikliği ise sosyal beceri yetersizliği olduğunu ortaya koymaktadır (Çimen, 2009). Tüm bu aç1klamalar dikkate alındığında, sosyal becerinin tek bir sınıflandırmaya dayanmadığı görülmektedir. Akkök'ün (2006) sınıflandırmasına bakıldığında; (1) ilişkiyi basslatma ve sürdürme becerileri, (2) grupla bir işi yürütme becerileri, (3) duygulara ve ifade edilmesine yönelik beceriler, (4) saldırgan davranışlarla başa çıkma becerileri, (5) stresle başa çıkma becerileri, (6) problem çözme ve planlama becerileri olduğu görülmüştür.

Sosyal Beceri Ölçeği’nin işaret değişkenler olarak maddelerinde en düşük madde toplam korelasyonu .30 düzeyindeyken en yüksek madde toplam korelasyonu .51 düzeyindedir. Madde toplam korelasyonunun yorumlanmasında, değeri .30 ve üzerinde olan maddelerin ölçülecek özelliği ayırt etme açısından yeterli olduğu kabul edilmektedir (Büyüköztürk, 2010; Erkuş, 2005). Madde analizi sonucunda ölçekteki maddelerin yeterli düzeyde ayırt edici özelliğe sahip olduğu, incelenen özellik bakımından cevaplayıcıları ayırt ettiği ve aynı özelliği ölçmeye yönelik maddeler oldukları şeklinde yorumlanabilir. Test tekrar test sonucu incelendiğinde iki uygulama arasında geçen zamandan sonra ölçeğin alt faktörlerinden olan işbirliği, özkontrol ve hakkını arama faktörlerinin .48 ile .51değerleri arasında olduğu görülmüştür. Ölçeğin toplam değerinin .65 düzeyinde olduğu sonucuna ulaşılmıştır $\left(r^{2}=.22-.42, p \leq .001\right)$. Bu bulgu, ölçeğin belirli bir zaman aralığına bağlı olarak kararlı bir yapıya sahip olduğunu belirtmektedir (Erkuş, 2005). Sonuca göre 
iki uygulama arasında kararlılık olduğu ve ölçekte orta düzeyde, pozitif ve anlamlı ilişki olduğu gözlenmiştir.

KR-21 formülü kullanılarak bulunan iç tutarlık katsayılarına bakıldığında işbirliği, özkontrol ve hakkını arama faktörlerinin .72 ile .78 düzeyindedir. Bir ölçek için hesap edilen güvenirlik katsayısının .70 ve daha yüksek olması, genel olarak test puanlarının güvenirliği açısından yeterli olduğu bilinmektedir (Büyüköztürk, 2010). KR-21 iç tutarlılık katsayısına ve test- tekrar test geçerliği sonuçlarına bakılarak ölçeğin güvenilir olduğu düşünülebilir. Geçerlik ve güvenirlik çalışması sonucunda ulaşılan bulgular, Japonya'da ölçeğin orijinaliyle Anme ve arkadaşlarının (2013) elde etmiş olduğu sonuçları destekler niteliktedir. Benzer ölçek geçerliğinde, geçerliği incelenen araçtan elde edilen puanlarla benzer yapıyı ölçtüğü kabul edilen aracın arasında olumlu yönde ilişki olması; farklı yapıyı ölçtüğü kabul edilen aracın puanlarıyla olumsuz yönde ilişkinin olması ya da anlamlı ilişkinin olmaması beklenir (Tavşancıl, 2002). Bu amaçla benzer ölçek geçerliğinin incelendiği altıncı alt problem için yapılan incelemede Sosyal Beceri Ölçeği’nin tüm alt ölçek puanları Sosyal Becerileri Değerlendirme Ölçeği, Okul Öncesi Çocuklar İçin Davranış Ölçeği, Anaokulu ve Anasınıfı Davranış Ölçeği ve Sosyal Beceri Geliştirme Sistemi ölçeklerinin alt faktörleriyle pozitif yönde anlamlı ilişkilendiğine ulaşılmıştır $(\phi \leq .001)$. Bu sonuçlar aracın geçerliğine yönelik önemli kanıtlar teşkil etmektedir. Özetle çalışmanın sonucunda Sosyal Beceri Ölçeği’nin Türk kültüründe geçerli ve güvenilir olduğu saptanmıştır. Okul öncesi dönemde, çocukların sosyal gelişimlerinin desteklendiği ve birçok sosyal becerilerin kazandırılma fırsatının olduğu göz önüne alındığında bu dönem çocukları için geliştirilen ölçeğin daha sonraki çalışma ve araştırmacılar tarafindan kullanılması oldukça önemlidir. Elde edilen bu sonuçlar kapsamında aşağıdaki öneriler geliştirilmiştir.

Bu araştırma Manisa ilinin Soma ilçesindeki okul öncesi dönem çocuklarının annelerinden toplanan veriler ile yürütülmüştür. Daha geniş bir kitle ve farklı illerde Sosyal Beceri Ölçeği kullanılarak sonuçlar arasındaki benzerlik- farklılıkları karşılaştırılabilir. Çalışmada Sosyal Beceri Ölçeği okul öncesi dönem çocuklarının annelerinden toplanan veriler ile değerlendirilmiştir. Daha sonraki araştırmalarda Sosyal Beceri Ölçeği öğretmenler tarafindan cevaplandırılabilir. Annelerden elde edilen bulgular ile öğretmenlerden elde edilen bulgular çoklu veri doğrulanmasında kullanılabilir. Farklı gelişen çocukların annelerinden veriler toplanıp, geçerlik güvenirlik çalışmaları yapılabilir. Geçerlik ve güvenirlik çalısması yapılan ölçeğin sosyal beceriler ile ilgili araştırma yapmak isteyen araştırmacılar tarafindan kullanılabileceği düşünülmektedir. Deneysel araştırmalarda çocukların sosyal beceri gelişimlerini izlemek amacıyla kullanılabilir. Sosyal becerinin gelişimsel sürecinin incelendiği boylamsal çalışmalarda ölçek, sosyal beceri düzeylerini ölçmede kullanılabilir. Karşılaştırmaya dayalı betimsel ya da ilişkisel araştırmalarda ölçek kullanılabilir. 


\section{KAYNAKÇA}

Acun Kapıkıran, N., İvrendi, A. B. ve Adak, A. (2006). Okul öncesi çocuklarında sosyal beceri: Durum saptamas1. Pamukekale Üniversitesi Eğitim Fakültesi Dergisi, 19(1); 19-27.

Akkök, F. (2006). İlkögrretimde sosyal becerilerin geliștirilmesi (Öğretmen el kitabı) (4. baskı). İstanbul: Özgür Yayınları.

Aksoy, P. ve Baran, G. (2020). Okul Öncesi Dönem Çocukları için Sosyal Becerileri Değerlendirme Ölçeği- Ebeveyn Formu: Bir Ölçek Uyarlama Çalışması. Akdeniz Eğitim Araștırmalar Dergisi, 14(31), 314-335. doi: 10.29329/mjer.2020.234.15

Aksu, G., Eser, M. T. ve Güzeller, C. O. (2017). Açımlayıcı ve doğrulayıı faktör analizi ile yapısal eşitlik modeli uygulamalar. Ankara: Detay Yayıncilık.

Alisinanoğlu F. ve Özbey, S. (2009). Anaokulu ve Anasınıfı Davranış Ölçeğinin geçerlilik ve güvenirlik çalışması. Mesleki Eğitim Fakültesi Dergisi, 1(173-198).

Anme, T., Shinohara, R., Sugisawa, Y., Tanaka, E., Watanabe, T. ve Hoshino, T. (2013). Validity and reliability of the Social Skill Scale (SSS) as an index of social competence for preschool children. Journal of Health Science, 3(1), 5-11.

Aslan, N. ve Arslan Cansever, B. (2007). Okuldaki sosyal etkinliklere katıllımda ebeveyn-çocuk etkileşimi (Kültürlerarası bir karşılaştırma). Ege Ë̆itim Dergisi, 8(1), 113-130.

Avcıoğlu, H. (2007). Sosyal Becerileri Değerlendirme Ölçeğinin geçerlik ve güvenirlik çalışması (46 Yaş). Abant İžet Baysal Üniversitesi Eğitim Fakültesi Dergisi, 7(2), 93-103.

Avcıŏlu, H. (2009). Etkinliklerle sosyal beceri ögretimi (3. Baskı). Ankara: Kök Yayıncılık.

Baroody, A.J., Clements, D.H. ve Sarama, J. (2019). Teaching and learning mathematics in early childhood programs. (Ed. C.P. Brown, M.B. McMullen ve N. File). The Wiley handbook of early childhood and education. Syf. 329-354. Medford, MA: John Wilet \& Sons, Inc.

Baylot Casey, L. ve Carter, S. L. (2016). Applied behavior analysis in early childhood education. An introduction to evidence-based interventions and teaching strategies. New York, NY: Routledge.

Bacanl, H. (2014). Eğitim psikolojisi. Ankara: Nobel Yayınlar1.

Büyüköztürk, Ş. (2010). Sosyal bilimler için veri analiz̧i el kitabı. Ankara: PegemA Yayıncıllk.

Çetin, F., Alpa Bilbay, A. ve Albayrak Kaymak, D. (2003). Cocuklarda sosyal beceriler. İstanbul: Epilson Yayinc1lik.

Çiftçi, İ. ve Sucuoğlu, B. (2013). Bilişsel süreş yaklaşımıyla sosyal beceri ögretimi. Ankara: Kök Yayıncılık.

Çimen, N. (2009). Okul öncesi eğitim programında altı yas grubu çocuklarn sosyal becerilerinin gerçekleşme düreyi. Yayımlanmamış yüksek lisans tezi, Atatürk Üniversitesi Sosyal Bilimler Enstitüsü.

$$
\begin{aligned}
& \text { Erken Çocukluk Çalışmaları Dergisi 2021 Journal of Early Childhood Studies } \\
& \text { Cilt } 5 \cdot \text { Sayı } 2 \cdot \text { Ekim } 2021 \quad \text { Volume } 5 \cdot \text { Issue } 2 \cdot \text { October }
\end{aligned}
$$


Dereobalı, N. (2005). Okul çağgnda çocuk gelişimi ve eğitimi 'şimdi okullu oldum'. İstanbul: Morpa Kültür Yayınları.

Erkuş, A. (2005). Bilimsel araștırma sarmalı. Ankara: Seçkin Yayınları.

Fazlıoğlu, Y., Okyay, L. ve Ilgaz, G. (2011). Okulöncesi ve Anaokulu Davranış Ölçeğinin geçerlik ve güvenirlik çalışması. Trakya Üniversitesi Sosyal Bilimler Dergisi, 13(1), 242-254.

Gresham, F. M. ve Elliot, S. N. (2008). SSIS Social skills improvement system: Ratin Scales Manual. Minneapolis: Pearson.

Gülay, H. ve Akman, B. (2009). Okul öncesi dönemde sosyal beceriler. Ankara: PegemA Yayınları.

Gülay, H. (2009). Okul öncesi dönemde akran ilişkileri. Bahkesir Üniversitesi Sosyal Bilimler Enstitüsü Dergisi, 12(22), 82-93.

Gültekin Akduman G., Günindi Y. ve Türkoğlu D. (2015). Okul öncesi dönem çocukların sosyal beceri düzeyleriyle davranış problemleri arasındaki ilişkinin incelenmesi. Uluslararası Sosyal Araştırmalar Dergisi, 37(8), 673-683.

Günindi, N. (2008). Okul öncesi kurumlarna devam eden altı yass çocuklarmm sosyal uyum becerileri ile anne babalarmm empatik becerileri arasındaki ilişkinin incelenmesi. Yayımlanmamış yüksek lisans tezi, Gazi Üniversitesi Eğitim Bilimleri Enstitüsü.

Güzeller, C. O., Eser, M. T. ve Aksu, G. (2018). JMetrik ile ölçme uygulamalar, Ankara: Maya Akademi.

Hambleton, R. K. (2006). Good practices for identifying differential item functioning. Medical Care, 44(11), 182-188.

Hancock, G. R. ve Mueller, R. O. (2010). The reviewer's guide to quantitative methods in the social sciences. New York, NY: Routledge.

Hargie, O. (2006). The handbook of communication skills. (3. Edition). New York: New York University Press.

Johnson, J. E. ve Mei-Hsuan Wu, V. (2019). Perspectives on play in early childhood care and education. (Ed. C.P. Brown, M.B. McMullen ve N. File). The Wiley handbook of early childhood and education. Syf 79-98. Medford, MA: John Wilet \& Sons, Inc.

Kline, T.J.B. (2005). Psychological testing. A practical approach to design and evaluation. California: Sage Publications, Inc.

Kamaraj, I. (2004). Sosyal Becerileri Dereceleme Ölçeğinin Türkşe'ye uyarlanması ve bes yaş çocuklarmm atılganlık sosyal becerisini kazanmalarnnda eğitici drama programmmn etkisi. Yayımlanmamış doktora tezi, Marmara Üniversitesi Eğitim Bilimleri Enstitüsü. 
Karaşahin, H. (2016). Sosyal Beceri Ölçeğinin Türkşe Formunun alternatif modellerinin incelenmesi. Yayınlamamış yüksek lisans tezi, Adnan Menderes Üniversitesi Sosyal Bilimler Enstitüsü.

Koçyiğit, S. ve Kayıl1, G. (2008). Montessori Eğitimi Alan ve Almayan Anaokulu Öğrencilerinin Sosyal Becerilerinin Karşılaştırılması. Selçuk Üniversitesi Sosyal Bilimler Enstitüsü Dergisi, 20, 511 516.

Koyuncu, İ., Aksu, G. ve Kelecioğlu, H. (2018). Mantel-Haenszel, lojistik regresyon ve olabilirlik oranı değişen madde fonksiyonu inceleme yöntemlerinin farklı yazılımlar kullanılarak karşılaştırılması. İlköğretim Online, 17(2), 909-925.

Kuder, G.F. ve Richardson, M.W. (1937). The theory of estimation of test reliability. Psychometrika, $2,151-160$.

Linacre, J. M. (2002).What do Infit and Outfit, Mean-square and Standardized mean? Rasch Measurement Transactions, 16(2), 878.

Matsunaga, M. (2010). How to factor-analyze your data right: Do's, don'ts, and how-to's. International Journal of Psychological Research, 3(1), 97-110.

Merrell, K. W. (2003). Preschool and Kindergarten Behavior Scales (2. Bask1). Examiner's Manual. Austin, Texas: Pro-ed. An International Publisher.

Mendez, J. L., Fantuzzo, J. ve Cicchetti, D. (2002). Profiles of social competence among lowincome African American preschool children. Child Development, 73(4), 1085-1100.

Mîndrilă, D. (2010). Maximum likelihood (ML) and diagonally weighted least squares (DWLS) estimation procedures: A comparison of estimation bias with ordinal and multivariate nonnormal data. International Journal of Digital Society, 1(1), 60 - 66.

Neslitürk S. (2013). Anne Değerler Ë̈itimi Programınn 5-6 Yaş çocuklarmm sosyal beceri dų̈eyine etkisi. Yayımlanmamış doktora tezi, Selçuk Üniversitesi Sosyal Bilimler Enstitüsü.

Neslitürk S. ve Deniz M. E. (2014). Sosyal Beceri Geliştirme Sistemi Aile Formu'nun Türk Kültürüne Uyarlanması: Güvenirlik ve geçerlik çalışması. Mustafa Kemal Üniversitesi Sosyal Bilimler Enstitïsü Dergisi, 11(26), 139-149.

Okyay, L. (2008). 6 yas grubu çocuklarn aile resimlerinin sosyo-kültü̈rel değiskeenler ve davranıs problemleri açısından karşılaştırılması. Yayımlanmamış yüksek lisans tezi, Trakya Üniversitesi Sosyal Bilimler Enstitüsü, Edirne.

Ömeroğlu, E., Büyüköztürk, Ş., Aydoğan, Y., Çakan, M., Kılıç Çakmak, E. ....... Karayol, S. (2014). Okul Öncesi Sosyal Beceri Değerlendirme Ölçeği Öğretmen Formunun geliştirilmesi: Geçerlik ve güvenirlik analizi. 21. Yü̈ynlda Eğitim ve Toplum, 3(8), 37-46.

Özbey, S. (2009). Anaokulu ve Anasinnf Davranış Ölçeğìnin (PKBS-2) geçerlik güvenirlik çalısması ve destekleyici eğitim programmm etkisinin incelenmesi. Yayımlanmamış doktora tezi, Gazi Üniversitesi Eğitim Bilimleri Enstitüsü, Ankara. 
Oertzen, T., Brandmaier, A. M. ve Tsang, S. (2013). Onyx user guide. İnternetten 10.01.2020 tarihinde http://onyx.brandmaier.de/ adresinden alınmıştır.

Riggio, R.E. (1986). Assessment of basic social skills. Journal of Personality and Social Psychology, 51(3), 649-660.

Winkelstern, J. A. ve Jongsma A. E. (2006). The early childhood education intervention treatment planner. Hoboken, NJ: John Wiley \& Sons.

Sireci, S. G. ve Mullane, L. A. (1994). Evaluating test fairness in licensure testing: the sensitivity review process. CLEAR Exam Review, 5(2), 22-27.

Seven, S. (2007). Ailesel faktörlerin altı yaş çocukların sosyal davranış problemlerine etkisi. Kuram ve Uygulamada Ë̆itim Yönetimi, 51, 477-499.

Tavşancıl, E. (2002). Tutumlarm ölçülmesi ve SPSS ile veri analiz̧i. Ankara: Nobel Yayınları.

Totan, T. (2020). Davranışçı kuramlar ve erken çocuklukta uygulama alanları. Yıldırım, G. Ve Özyılmaz, G. (Ed.), Erken çocuklukta ögrenme yaklaşımları. Ankara: PegemA Yayınları.

Yaşar, M. (2015). Her yönüyle okul öncesi eğitim-1. F. Turan, A. İ. Yükselen, (Ed.), Okul öncesi dönemde sosyal-duygusal gelişim içinde (275-288). Ankara: Hedef CS Yayınc1lık.

Yeşilyaprak, B. (2008). Eğitim psikolojisi. Ankara: PegemA Yayınları.

Yıldız Bıçakçı, M. (2015). Bebeklik ve ilk çocukluk döneminde (0-36 Ay) Gelişim: Eğiten Kitap Yayıncılık.

Ziv, Y. (2013). Social Information Processing Patterns, social skills, and school readiness in preschool children. Journal of experimental child psychology, 114(2), 306-320. 